\title{
Protein losing enteropathy associated with collagen diseases
}

Akito Tsutsumi, Takao Sugiyama, Ryutaro Matsumura, Makoto Sueishi, Katsuhiko Takabayashi, Takao Koike, Hisao Tomioka, Sho Yoshida

\begin{abstract}
Four patients with collagen diseases are described, who developed protein losing enteropathy in the course of their disease. Their protein losing enteropathies subsided after treatment with $60 \mathrm{mg} /$ day oral prednisolone. Immunohistological studies of the small intestine showed deposits of $\mathrm{C3}$ in the capillary walls of villi in two patients. Increased capillary permeability due to autoimmune phenomena may have a role in the pathogenesis of protein losing enteropathy associated with collagen diseases.
\end{abstract}

Protein losing enteropathy is characterised by leakage of serum protein into the gastrointestinal tract, which results in hypoproteinaemia and generalised oedema. Protein losing enteropathy is associated with a wide variety of disorders, but is an unusual manifestation of collagen diseases. $^{1}$ To our knowledge there are some single case reports of protein losing enteropathy associated with systemic lupus erythematosus, ${ }^{2-13}$ but multiple cases from a single institute have not been reported.

We previously reported a case of Sjögren's syndrome with protein losing enteropathy, ${ }^{14}$ but we have since encountered three cases of collagen diseases (two systemic lupus erythematosus (SLE), one mixed connective tissue disease) with protein losing enteropathy, suggesting that this complication may not be as rare as is generally considered.

\section{Case reports}

CASE 1

A 47 year old Japanese woman had fever and lymphadenopathy in June 1983. Laboratory examinations showed leucocytopenia and a positive titre for antinuclear antibody, but symptoms subsided without treatment. In August 1985 proteinuria was noted and the patient had a dry mouth and dry eyes. Sialography and lip biopsy were performed, and a diagnosis of Sjögren's syndrome was made. By November 1985 she had developed pretibial oedema and increased body weight, and was admitted to our hospital.

Laboratory investigations showed urinary protein $0.2 \mathrm{~g} /$ day; urinary sediment normal; erythrocyte sedimentation rate $77 \mathrm{~mm} / \mathrm{h}$; red blood cells $4 \cdot 19 \times 10^{12} / \mathrm{l}$; haemoglobin $126 \mathrm{~g} / 1$; packed cell volume 0.38 ; white blood cells $3.7 \times 10^{9} / 1$; platelets $216 \times 10^{9} / 1$; renal and hepatic findings normal; total protein $37 \mathrm{~g} / \mathbf{l}$ (albumin $33.6 \%, \alpha_{1} 4.8 \%, \alpha_{2} 29.9 \%, \beta 12 \cdot 2 \%, \gamma 19.5 \%$ ); IgG 10.2 g/l (normal 9-18); IgA $2 \cdot 6$ g/l (0.3-3.5);
IgM 2.7 g/l (0.7-2.4); total cholesterol 6.5 $\mathrm{mmol} / \mathrm{l} \quad(3 \cdot 2-6 \cdot 3) ;$ triglyceride $1.3 \mathrm{mmol} / \mathrm{l}$ (0.4-1.7); antinuclear antibodies $1 / 64$ (speckled pattern); anti-SS-A antibody $1 / 16$; antimicrosome antibody $1 / 100$; C3 $585 \mathrm{mg} / \mathrm{l}$ (500-1200); C4 $275 \mathrm{mg} / \mathrm{l} \quad(150-500)$; triiodothyronine $5 \mathrm{pmol} / \mathrm{l}(17-35)$; thyroxine $66.5 \mathrm{nmol} / \mathrm{l}(10.3$ 29.6); thyrotrophin 0.98 arb unit $(<5)$. Antibodies to thyroid, SS-B, RNP, and Sm were negative.

A barium radiograph of the gastrointestinal tract showed diffuse oedema of the small intestine, which was confirmed by endoscopic investigation. Biopsy of the small intestine showed oedema, mononuclear cell infiltration, and mild dilatation of the lymphatic vessels. Immunohistological studies showed deposits of C3 and fibrinogen in the capillary walls of the lamina propriae in the villi. Immunohistological studies for $\operatorname{IgG}, \operatorname{IgA}, \operatorname{IgM}$, and $\mathrm{Clq}$ were negative. A barium radiograph of the colon was normal. A chest radiograph showed normal cardiovascular shadow and mild pleural effusion. Excretion of ${ }^{125}$ I labelled polyvinyl pyrrolidine (PVP test) was $2.5 \%$ (normal $<0.5 \%$ ), which confirmed the diagnosis of protein losing enteropathy.

Oral prednisolone ( $60 \mathrm{mg} /$ day) was given, and after eight weeks the PVP test was reduced to $0.77 \%$ and total protein and albumin became normal. She continues to be well with $10 \mathrm{mg}$ prednisolone every two days, but mild dilatation of the lymphatic vessels in the small intestine still remained 12 weeks after the start of steroid treatment.

CASE 2

A 30 year old Japanese woman developed joint pain and joint swelling in 1981. In December 1982 she developed alopecia, leg oedema and fever, and she was admitted to our hospital in March 1983.

Laboratory investigations showed urinary protein $0.46 \mathrm{~g} /$ day; urinary sediment normal; erythrocyte sedimentation rate $103 \mathrm{~mm} / \mathrm{h}$; red blood cells $3.01 \times 10^{12} / 1$; haemoglobin $90 \mathrm{~g} / \mathrm{l}$; white blood cells $4.4 \times 10^{9} / 1$; platelets $365 \times 10^{9} / 1$; renal and hepatic findings normal; total protein $44 \mathrm{~g} / \mathrm{l}$; albumin $19 \mathrm{~g} / \mathrm{l} ; \mathrm{IgG} 10.9 \mathrm{~g} / \mathrm{l} ; \mathrm{IgA} 5.0 \mathrm{~g} / \mathrm{l}$; IgM $0.7 \mathrm{~g} / \mathrm{l}$; total cholesterol $4.4 \mathrm{mmol} / \mathrm{l}$; triglyceride $2.8 \mathrm{mmol} / \mathrm{l}$; antinuclear antibodies 1/160 (homogeneous pattern); anti-DNA antibody $72 \mathrm{unit} / \mathrm{ml}$ (normal <10); anti-SS-A antibody $1 / 64$; C3 $305 \mathrm{mg} / \mathrm{l}$; C4 $115 \mathrm{mg} / \mathrm{l}$; triiodothyronine $66 \mathrm{pmol} / \mathrm{l}$; thyroxine $55.3 \mathrm{nmol} / \mathrm{l}$; thyrotrophin $<1.3$ arb units. Antibodies to SS$\mathrm{B}, \mathrm{RNP}$, and $\mathrm{Sm}$ were all negative. 
A barium radiographic series of the gastrointestinal tract showed a normal stomach, oedematous change of the small intestine, and normal colon. Biopsy of the small intestine showed oedema, mononuclear cell infiltration, and mild dilatation of the lymphatic vessels. Echocardiography showed mild pericardial effusion, but no signs of pleural effusion were seen in the chest radiograph. The result of the PVP test was $2 \cdot 15 \%$, which confirmed the loss of protein to the gastrointestinal tract. She was diagnosed as having SLE associated with protein losing enteropathy.

After four weeks' treatment with oral prednisolone $60 \mathrm{mg} /$ day, serum protein and albumin became normal, but as the steroid dose was tapered she had abdominal distention and constipation. An abdominal radiograph showed retention of gas in the gastrointestinal tract. Although her SLE and protein losing enteropathy is stable with $17.5 \mathrm{mg} /$ day oral prednisolone, her paralytic ileus has not fully recovered.

CASE 3

A 26 year old Japanese woman had arthralgia, morning stiffness, and facial oedema in March 1987. In late March she developed myalgia, muscle weakness, swollen fingers, and heliotrope rash, and she was admitted to our hospital.

Laboratory investigations showed leucopenia, thrombocytopenia, a positive titre for antinuclear antibody and anti-RNP antibody, and raised aspartate transaminase, lactate dehydrogenase, and creatine kinase concentrations. She was diagnosed as having mixed connective tissue disease, but her symptoms subsided with $50 \mathrm{mg} /$ day indomethacin, which was then discontinued. In March 1988 she developed fever and leg oedema and was admitted to hospital.

Laboratory examinations showed urinary protein negative; urinary sediment normal; red blood cells $4.38 \times 10^{12} / 1$; haemoglobin $136 \mathrm{~g} / \mathrm{l}$; packed cell volume 0.41 ; white blood cells $5.6 \times 10^{9} / 1$; platelets $46 \times 10^{9} / 1$; aspartate transaminase $44 \mathrm{IU} / \mathrm{l}$; alanine transaminase $42 \mathrm{IU} / \mathrm{l}$;

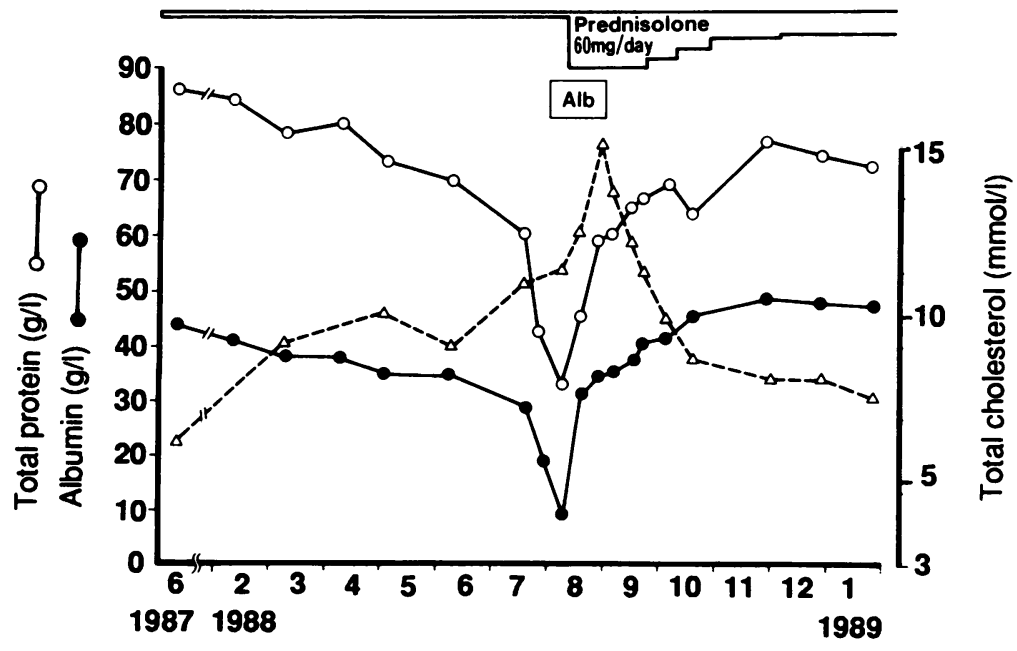

Figure 1 Clinical course of case 4. Values of total protein $\left(\mathrm{O}_{-} \mathrm{O}\right)$, albumin $\left(\mathrm{O}_{-}\right)$ total cholesterol $(\triangle--\triangle)$, and doses of prednisolone are shown. lactic dehydrogenase $130 \mathrm{IU} / \mathrm{l}$; creatine kinase $19 \mathrm{IU} / \mathrm{l}$; renal findings normal; total protein $43 \mathrm{~g} / \mathrm{l}$ (albumin 39.3\%, $\alpha_{1} 6.6 \%, \alpha_{2} 23 \cdot 6 \%, \beta$ $7 \cdot 3 \%, \gamma 23 \cdot 2 \%$ ); IgG $15 \cdot 87 \mathrm{~g} / \mathrm{l} ; \operatorname{IgA} 1 \cdot 16 \mathrm{~g} / \mathrm{l}$; IgM $740 \mathrm{mg} / \mathrm{l}$; total cholesterol $6.9 \mathrm{mmol} / \mathrm{l}$; triglyceride $4.5 \mathrm{mmol} / \mathrm{l}$; antinuclear antibodies 1/4096 (speckled pattern); anti-SS-A antibody 1/64; anti-DNA antibody 71 unit/ml; anti-RNP antibody greater than $1 / 256 ; \mathrm{C} 3450 \mathrm{mg} / \mathrm{l} ; \mathrm{C} 4$ $120 \mathrm{mg} / \mathrm{l}$; triiodothyronine $7 \mathrm{pmol} / \mathrm{l}$; thyroxine $6.9 \mathrm{nmol} / 1$; thyrotrophin 2.84 arb unit. Antibodies to SS-B and Sm were negative.

Biopsy of the small intestine showed oedema of the submucosa and mild dilatation of the lymphatic vessels. Endoscopic examination of the colon showed no macroscopic abnormality. A chest radiograph showed normal cardiovascular shadow and right pleural effusion. Mild amounts of ascites and pericardial effusion were observed by echosonogram. A PVP test was over $7 \%$ and the presence of protein losing enteropathy was confirmed.

Her total protein and albumin reached normal within four weeks of treatment with oral prednisolone $60 \mathrm{mg} /$ day. During a course of steroid treatment she had an embolic episode of the right brachial artery, but anticoagulant treatment produced favourable results. The coagulative effects of prednisolone and hypoproteinaemia were considered as causative factors of the embolism. She is now well with $20 \mathrm{mg}$ oral prednisolone every two days.

\section{CASE 4}

A 16 year old Japanese girl with a facial rash and fever was admitted to our hospital in September 1982. Pleural effusion, a high titre of antinuclear antibody and anti-DNA antibody, and leucopenia were found and a diagnosis of SLE was made. Treatment with oral prednisolone 60 $\mathrm{mg} /$ day was started, and her condition was good with a maintenance dose of $15 \mathrm{mg}$ prednisolone every two days. Hypercholesterolaemia was noticed in November 1987, but she remained without symptoms. She developed pretibial oedema in June 1988, had gained weight and was easily tired by July, and was admitted to our hospital in August 1988 (fig 1).

Laboratory investigations showed urinary protein $0.17 \mathrm{~g} /$ day; urinary sediment normal; red blood cells $4.94 \times 10^{12} / 1$; haemoglobin 148 $\mathrm{g} / \mathrm{l}$; white blood cells $2 \cdot 13 \times 10^{9} / 1$; platelets $60.5 \times 10^{9} / \mathrm{l}$; total protein $35 \mathrm{~g} / \mathrm{l}$; albumin $9 \mathrm{~g} / \mathrm{l}$; IgG $10 \cdot 14 \mathrm{~g} / 1 ; \operatorname{IgA} 2 \cdot 17 \mathrm{~g} / \mathrm{l} ; \operatorname{IgM} 3.91 \mathrm{~g} / \mathrm{l}$; total cholesterol $10.6 \mathrm{mmol} / \mathrm{l}$; triglyceride 5.65 $\mathrm{mmol} / \mathrm{l}$; anti-DNA antibody $24 \mathrm{unit} / \mathrm{ml}$; antimicrosome antibody 1/100; C3 $320 \mathrm{mg} / \mathrm{l} ; \mathrm{C} 4$ $60 \mathrm{mg} / \mathrm{l}$; triiodothyronine $19 \mathrm{pmol} / \mathrm{l}$; thyroxine $8.5 \mathrm{nmol} / \mathrm{l}$; thyrotrophin 1.71 arb units. Antibodies to RNP and Sm were negative. Mild ascites and pleural effusion were noted.

Biopsy of the lip showed grade IV change of the small salivary gland and she was diagnosed as having SLE with Sjögren's syndrome. Biopsy of the small intestine showed oedema, mild mononuclear cell infiltration, and deposits of $\mathrm{C} 3$ in the capillary walls of the lamina propriae in the villi, but dilatation of the lymphatic walls was not noted (fig 2). Immunohistological 

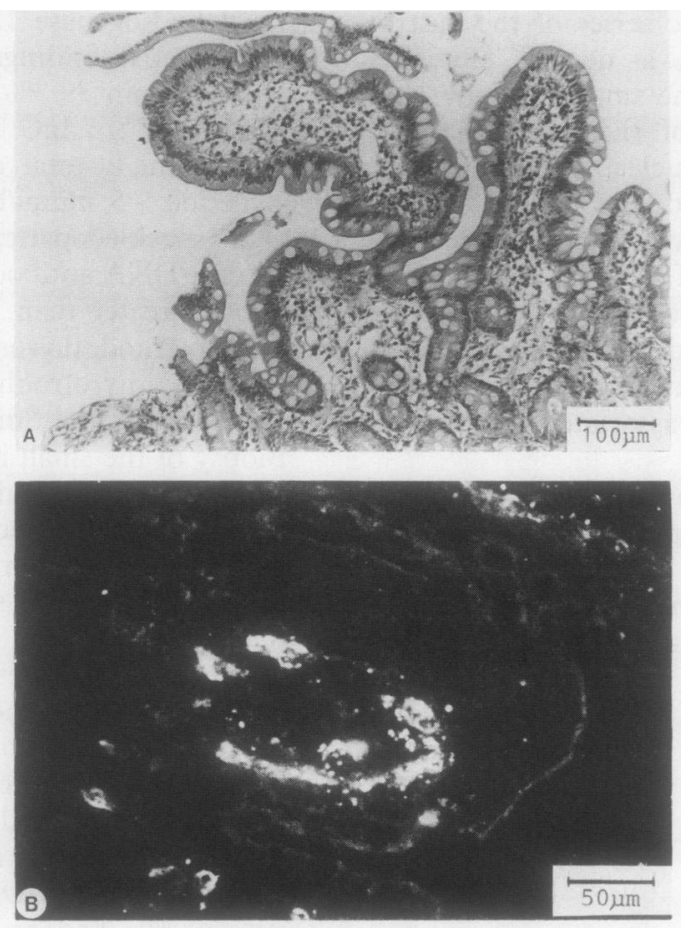

Figure 2 (A)Biopsyspecimen from the jejunum of patient 4. Oedema and mild mononuclear cell infiltration is shown. (Haematoxylin and eosin.) (B) Immunofluorescence micrograph showing deposits of $C 3$ in the capillary walls of the lamina propriae in the vill.

studies for IgG, IgA, IgM, fibrinogen, and Clq were negative.

She recovered promptly from protein losing enteropathy after treatment with $60 \mathrm{mg} /$ day oral prednisolone, and she is well with $20 \mathrm{mg} /$ day oral prednisolone. A PVP test after treatment with prednisolone was normal.

\section{Discussion}

We have described here four cases of protein losing enteropathy which occurred in the course of collagen diseases. These patients had not taken non-steroidal anti-inflammatory drugs before the onset of the protein losing enteropathy, nor had they shown any signs or symptoms suggesting inflammatory bowel diseases, such as Crohn's disease. Therefore, their protein losing enteropathy was considered to be a complication of their collagen disease.
Protein losing enteropathy is a rare complication of collagen diseases, and the reported cases are summarised in the table. Most of the cases were diagnosed as SLE, but there are some atypical cases included which satisfy three or less of the 1982 revised criteria for the classification of SLE. ${ }^{15}$ Some of these atypical cases might have had Sjögren's syndrome. Five, including our two cases, had chronic thyroiditis. The correlation between chronic thyroiditis and protein losing enteropathy needs more investigation, but as the thyroid function varies from hyperthyroid to hypothyroid, we assume that thyroid function has no direct effect on the pathogenesis of protein losing enteropathy. Laboratory investigation showed that total serum cholesterol tends to be high. Protein losing enteropathy, especially associated with primary intestinal lymphangiectasia, usually causes hypocholesterolaemia, hypoproteinaemia, hypoalbuminaemia, and hypogammaglobulinaemia. It is generally accepted that in intestinal lymphangiectasia, loss of lymphatic fluid causes both hypoproteinaemia and hypocholesterolaemia. ${ }^{16}$ On the other hand, increased capillary permeability has been reported in patients with collagen diseases. ${ }^{17}$ Most cholesterol in sera exists as very large components, such as very low density lipoprotein, low density lipoprotein and high density lipoproteincholesterol. The smallest compound, high density lipoprotein-cholesterol, has a molecular weight of around 500000 , which is too large to be lost in a capillary transudate. Hypercholesterolaemia will result, as with hypoproteinaemia in nephrotic syndrome.

Immunohistological studies in cases 1 and 4 showed deposits of C3 (and fibrinogen in case 4) in the capillary walls of the lamina propriae in the villi. This supports an immune mechanism as the underlying cause of the protein loss. Eight cases, including our three cases, had mild dilatation of the lymphatic vessels, but the five reported cases, which underwent lymphangiography, showed no evidence of fluid loss to the intestinal tract. Furthermore, in our case 1 the lymphangiectasia persisted after the protein losing enteropathy subsided, so it is unlikely that lymphangiectasia is the main cause of protein losing enteropathy in collagen diseases. Recently, a case of protein losing enteropathy in

Summary of reported cases of protein losing enteropathy associated with collagen diseases

\begin{tabular}{|c|c|c|c|c|c|c|c|c|c|c|c|c|}
\hline $\begin{array}{l}\text { Patient } \\
\text { no }\end{array}$ & $\begin{array}{l}\text { Age } \\
\text { (years) }\end{array}$ & Sex & Diagnosis & Thyroid & $\begin{array}{l}T P^{*} \\
(g / l)\end{array}$ & $\begin{array}{l}A l b^{*} \\
(g / l)\end{array}$ & $\begin{array}{l}\gamma-G l^{*} \\
(\mathrm{~g} / \mathrm{l})\end{array}$ & $\begin{array}{l}U P^{*} \\
(\mathrm{~g} / \text { day })\end{array}$ & $\begin{array}{l}T \text {-chol } \\
\text { (mmolll) }\end{array}$ & Histology & $\begin{array}{l}\text { Effect of } \\
\text { steroids }\end{array}$ & References \\
\hline $\begin{array}{r}1 \\
2 \\
3 \\
4 \\
5 \\
6 \\
7 \\
8 \\
9 \\
10 \\
11 \\
12 \\
13\end{array}$ & $\begin{array}{l}59 \\
50 \\
23 \\
29 \\
12 \\
22 \\
12 \\
29 \\
29 \\
22 \\
21 \\
33 \\
47 \\
30 \\
26 \\
16\end{array}$ & $\begin{array}{l}\mathbf{F} \\
\mathbf{F} \\
\mathbf{F} \\
\mathbf{F} \\
\mathbf{M} \\
\mathbf{F} \\
\mathbf{F} \\
\mathbf{F} \\
\mathbf{F} \\
\mathbf{F} \\
\mathbf{F} \\
\mathbf{F} \\
\mathbf{F} \\
\mathbf{F} \\
\mathbf{F} \\
\mathbf{F}\end{array}$ & $\begin{array}{l}\text { SLE* } \\
\text { SLE } \\
\text { SLE } \\
\text { SLE } \\
\text { SLE } \\
\text { SLE } \\
\text { SLE } \\
\text { SLE } \\
\text { SLE } \\
\text { SLE } \\
\text { SLE } \\
\text { SLE } \\
\text { SS* } \\
\text { SLE } \\
\text { MCTD* } \\
\text { SLE }\end{array}$ & $\begin{array}{l}\text { ND* } \\
\text { CT* } \\
\text { ND } \\
\text { ND } \\
\text { Normal } \\
\text { ND } \\
\text { CT } \\
\text { Goitre } \\
\text { Low T3*? } \\
\text { CT } \\
\text { Normal } \\
\text { ND } \\
\text { CT } \\
\text { CT } \\
\text { Normal } \\
\text { Normal }\end{array}$ & $\begin{array}{l}56 \\
53 \\
38 \\
48 \\
42 \\
30 \\
\text { ND } \\
49 \\
\text { ND } \\
\text { ND } \\
45 \\
45 \\
37 \\
44 \\
43 \\
35\end{array}$ & $\begin{array}{r}19 \\
21 \\
12 \\
13 \\
13 \\
7 \\
12 \\
21 \\
14 \\
17 \\
5 \\
19 \\
19 \\
19 \\
17 \\
9\end{array}$ & $\begin{array}{c}\uparrow \\
10 \cdot 8 \\
6 \cdot 6 \\
17 \cdot 9 \\
8 \cdot 6 \\
\downarrow \\
\downarrow \\
12 \\
\text { Normal } \\
\text { Normal } \\
5 \\
14 \cdot 6 \\
6 \\
7 \\
10 \\
7\end{array}$ & $\begin{array}{l}- \\
+ \\
- \\
0.3 \\
\text { Trace } \\
0.2 \\
0.05 \\
- \\
- \\
<0.2 \\
0.4 \\
- \\
<0.5 \\
0.2 \\
-0.2 \\
0.2\end{array}$ & $\begin{array}{l}2 \cdot 8 \\
7 \cdot 2 \\
\text { Normal } \\
\text { ND } \\
8 \cdot 3 \\
10 \cdot 2 \\
9 \cdot 0 \\
10 \cdot 6 \\
10 \cdot 0 \\
\text { ND } \\
9 \cdot 6 \\
5 \cdot 9 \\
6 \cdot 5 \\
4 \cdot 4 \\
6.9 \\
10 \cdot 6\end{array}$ & $\begin{array}{l}\text { Normal } \\
\text { Normal } \\
\text { ND } \\
\text { MI*, LAE* } \\
\text { ND } \\
\text { Venulutis } \\
\text { LAE } \\
\text { MI } \\
\text { Oedema } \\
\text { MI } \\
\text { MI } \\
\text { LAE } \\
\text { MI, LAE } \\
\text { MI, LAE } \\
\text { LAE } \\
\text { MI, LAE }\end{array}$ & $\begin{array}{l}+ \\
+ \\
+ \\
+ \\
+ \\
+ \\
+- \\
+ \\
+ \\
+ \\
+ \\
+ \\
+ \\
+ \\
+ \\
+\end{array}$ & $\begin{array}{l}2 \\
3 \\
4 \\
5 \\
6 \\
7 \\
8 \\
9 \\
10 \\
11 \\
12 \\
13 \\
\text { Case } 1 \\
\text { Case } 2 \\
\text { Case } \\
\text { Case } 4\end{array}$ \\
\hline
\end{tabular}

${ }^{*} \mathrm{TP}=$ total protein $(65-82 \mathrm{~g} / \mathrm{l}) ; \mathrm{Alb}=$ albumin $(39-51 \mathrm{~g} / 1) ; \gamma-\mathrm{Gl}=$ gammaglobulin $(7 \cdot 3-17 \cdot 3 \%$ of total protein); UP=urinary protein; T-chol=total cholesterol $(3 \cdot 2-6 \cdot 3 \mathrm{mmol} / \mathrm{l}) ; \mathrm{SLE}=$ systemic lupus erythematosus; $\mathrm{SS}=$ Sjögren's syndrome; $M C T D=$ mixed connective tissue disease; $\mathrm{ND}=$ not described; $\mathrm{CT}=$ chronic thyroiditis; $\mathrm{T} 3=$ triiodothyronine; $\mathrm{MI}=$ mononuclear cell infiltration in the lamina tissue disease; $\mathrm{N}=$ not described; Normal values used in our institute are shown in parentheses. 
a patient with positive antinuclear antibodies, anti-SS-A and anti-SS-B antibodies has been reported. ${ }^{18}$ In this case immunohistological studies showed IgG, IgM, Clq, and C3 deposits in the walls of capillaries of the lamina propria. In our patients we showed the presence of $\mathrm{C} 3$ but not IgM, IgG, or Clq in the lamina propria. The reason for this discrepancy is not clear, but complement mediated vascular injury not dependent on immune complex deposition has been suggested, ${ }^{19} 20$ and this may have some role in the pathogenesis of protein losing enteropathy in our patients. This hypothesis proposes that intravascular activation of complement triggers release of anaphylatoxins, such as C3a and $\mathrm{C5a}$ and other complement split molecules, into the circulation. These split products cause increased capillary permeability and also attract and activate cells such as neutrophils and platelets.

The reported cases of protein losing enteropathy in collagen diseases had all had steroid treatment, doses varying from 15 to $100 \mathrm{mg} /$ day. Unresponsiveness to low dose prednisolone has been reported. ${ }^{8} 9$ All our patients recovered from protein losing enteropathy with $60 \mathrm{mg} /$ day of prednisolone without major side effects, and we favour this dose as initial treatment.

Thus, in conclusion, patients with collagen disease with undefined hypoproteinaemia should be investigated for underlying protein losing enteropathy.

1 Waldmann T A. Protein-losing gastroenteropathies. In: Bockus H L, ed. Gastroenterology. Vol 2. 3rd ed. Philadelphia: Saunders, 1976: 361-85

2 Pachas $W N$, Linscheer W G, Pinals R S. Protein-losing enteropathy in systemic lupus erythematosus. $A m \mathcal{F}$ Gastroenterol 1971; 55: 162-7.
3 Ueda $M$, Yamamoto I, Hasaya $K$, Takeda R. A case of systemic lupus erythematosus with protein losing enteropathy. Naika 1975; 36: 333-6. (In Japanese.)

4 Trentham D E, Masi A T. Systemic lupus erythematosus with a protein losing enteropathy. $\mathcal{F} A M A 1976 ; 236: 287-8$.

5 Pereira A S, Pereira Filho R A, Trevisan M A S, Magelhaes A F N. Intestinal lymphangiectasia in systemic lupus erythematosus. Arq Gastroenterol 1980; 17: 210-2.

6 Tsukahara M, Matsuo K, Kojima H. Protein losing enteropathy in a boy with systemic lupus erythematosus. f Pediatr 1980; 97: 778-80.

7 Weiser M M, Andres G A, Brentiens J R, Evans J T, Reichlin $M$. Systemic lupus erythematosus and intestinal venulitis. Gastroenterology 1981; 81: 570-9.

8 Chase G J, O'Shea P A, Collins E, Brem A S. Protein-losing enteropathy in systemic lupus erythematosus. Hum Pathol 1982; 13: 1053-5.

9 Takagi S, Oshimi K, Sumiya M, Gonda N, Kano S, Takaku $F$. Protein-losing enteropathy in systemic lupus erythematosus. Am $\mathcal{F}$ Gastroenterol 1983; 78: 152-4.

10 Wood M L, Foulds I S, French M A. Protein losing enteropathy due to systemic lupus erythematosus. Gut 1984; 25: 1013-5.

11 Heck L W, Alarcon G S, Ball G V, et al. Pure red cell aplasia and protein-losing enteropathy in a patient with systemic lupus erythematosus. Arthritis Rheum 1985; 28: 1059-61.

12 Casteneda S, Moldenhauer F, Herrero-Beaumont G, Yanez R. Protein losing enteropathy as the initial manifestation of R. Protein losing enteropathy as the initial manifestation of
systemic lupus erythematosus. $\mathcal{f}$ Rheumatol 1985; 12: systemic

13 Monballyu J, Hauglustaine D, Geboes K, Desmet V, Michielsen $P$. Protein-losing enteropathy in systemic lupus erythematosus. Digestion 1985; 31: 243-6.

14 Sugiyama T, Koike T, Imaizumi T, et al. A case of Sjögren's syndrome associated with protein losing enteropathy. fapanese fournal of Clinical Immunology 1988; 11: 80-5. (In Japanese.)

15 Tan E M, Cohen E S, Fries J F, et al. The 1982 revised criteria for the classification of systemic lupus erythematosus. Arthritis Rheum 1982; 25: 1271-7.

16 Tsuchiya $M$, Asakura $H$. Protein-losing gastroenteropathy. Taisha 1970; 7: 40-6. (In Japanese.)

17 Marks J, Birkett D A, Shuster S. "Capillary permeability" in patients with collagen vascular diseases. Br Med $\mathcal{F} 1972$; i: p82-4.

18 Itoh K, Sasaki T, Sawai T, et al. Protein-losing gastroenteropathy in association with immune deposits in
gastrointestinal mucosal capillaries. Am $\mathcal{f}$ Gastroenterol gastrointestinal muc

19 Hopkins P, Belmont H M, Buyon J, Philips M, Weissmann $G, A$ bramson $S B$. Increased levels of plasma anaphylatoxins in systemic lupus erythematosus predict flares of the disease and may elicit vascular injury in lupus cerebritis. Arthritis Rheum 1988; 31: 632-41.

20 Hugli T E. Structure and function of the anaphylatoxins. Springer Semin Immunopathol 1984; 7: 193-219. 